


\title{
Urban heat island in Padua, Italy: simulation analysis and mitigation strategies
}

\author{
Luca Battistella - Department of Management and Engineering - University of Padua, Italy - \\ luca.battistella.2@studenti.unipd.it \\ Marco Noro - Department of Management and Engineering - University of Padua, Italy - \\ marco.noro@unipd.it
}

\begin{abstract}
The Urban Heat Island effect has been widely studied in large cities around the world, more rarely in medium-size ones. The paper reports on the study of the UHI phenomenon in Padua, a medium-size city in the northeast of Italy, one of the most industrialized and developed parts of the country.

Experimental measurements were carried out during summer2012, recording the main thermohygrometric variables by mobile surveys along an exact path crossing different zones of the city area (urban, sub-urban and rural). Some measurements in situ in characteristic sites of the city area (like the city centre, high and low density populated residential zones, industrial zone, rural zone) were carried out in order to evaluate thermal comfort indexes. The analysis of the data highlights the presence of the UHI effect with different magnitudes depending on the function of the zone of the city. In the city centre, a historical zone, the effect was up to $7^{\circ} \mathrm{C}$.

The ENVImet simulation model was used in order to quantify possible increases in thermal comfort as a consequence of some mitigation strategies. In particular, a very famous square of the city (Prato della Valle) was analysed: it can be considered representative of the phenomenon because of the size and so the very different characteristics from the UHI effect point of view. Two scenarios were analysed besides the actual one ("AsIs" scenario): "Green ground" (halving the asphalt surface and doubling the green and plants surface) and "Cool Pavements" (increasing the albedo of impervious horizontal surfaces).
\end{abstract}

The simulations results are presented both in terms of UHI intensity (difference in air dry-bulb temperature between Prato della Valle and a reference rural site) and in terms of mean radiant temperature and thermal comfort sensation. The results are presented both in spatial and temporal terms for a typical summer day. The "Green ground" scenario allows up to a $1.4{ }^{\circ} \mathrm{C}$ and $3{ }^{\circ} \mathrm{C}$ decrease in air temperature, respectively during the night and the day. The same items for the "Cool Pavements" scenario are, respectively, 1.8 and $4{ }^{\circ} \mathrm{C}$.

\section{Introduction}

As is well known, the Urban Heat Island phenomenon (UHI) is the systematic higher air temperature of an urban environment with respect to a rural one. This results from many causes that interact with one another, according to the particular situation of each city (Lazzarin, 2011). Briefly, the main factors are the following:

- the structure of urban canyons that affect the shortwave radiation heat exchange capacity of the urban surfaces towards the sky;

- the typically low albedo of the urban surfaces that increase the heat absorbed by buildings, pavements, roads and roofs;

- the anthropogenic heat produced by heat engines of the motorcars and chillers condensation heat;

- the greenhouse effect that is amplified by the higher pollutant concentration in the urban atmosphere; 
- the shortage of green areas that increases the heat exchange with air and decreases the evaporative cooling effect due to the lack of evapotranspiration of trees and grass.

The literature on the UHI effect is very rich; for the sake of brevity refer to the authors' previous work (Noro et al., 2014a) to find some references. UHI has been studied worldwide (Athens, London, Berlin, Vancouver, Montreal, New York, Tokyo, Hong Kong for example) since the sixties (Santamouris, 2007). In Italy, only a few studies are available for some major cities like Bologna (Zauli Sajani et al., 2008), Milan (Bacci and Maugeri, 1992), Florence (Petralli et al., 2006) (Petralli et al., 2009) (Petralli et al., 2011) and Rome (Fabrizi et al., 2010). Very few data are available concerning the existence of the urban heat island phenomenon in medium-size cities, the most widespread in Italy (Modena (Bonafè, 2006) and Trento (Lora et al., 2006) (Giovannini et al., 2011) for example), and none in the Veneto Region in the northeast of Italy. The University of Padua has been studying the Padua city's UHI effect since 2010. In previous works the authors have described the results of the 2010, 2011 and 2012 measurement campaigns done by the research group of the Department of Environmental Agronomy and Crop Productions and by the authors themselves (University of Padua) (Busato et al., 2014) (Noro et al., 2014a). In other previous studies, the authors described the activities on the simulation of UHI in characteristic sites of the fabric of the city of Padua developed within the framework of the European Project "UHI"1 (Noro and Lazzarin, 2014) (Noro et al., 2014b).

In this paper, the use of the ENVImet simulation model allowed to investigate the effects of possible mitigation strategies in one of the most characteristic sites of the city, Prato della Valle.

\section{UHI Mitigation Strategies by Simulations \\ 2.1 Methods}

In order to accurately simulate the physics of the atmospheric boundary layer of an urban area, the

1 “UHI - Development and application of mitigation and adaptation strategies and measures for counteracting the global Urban Heat Islands phenomenon" (3CE292P3). modeling software should meet the following requirements (Huttner, 2012) (Xiaoshan et al., 2012):

- $\quad$ the grid size of the model area should be small enough to resolve buildings, i.e. grid size $\leq 10$ $\mathrm{m}$;

- the model should implement the energy balance of surfaces of all types;

- the simulation of the physical and physiological properties of plants should be included;

- the calculation of the atmospheric processes should be prognostic and transient.

The three-dimensional microclimate model ENVImet (www.envi-met.com) (Bruse and Fleer, 1998 ) is one of the few microscale models that fulfill all of the above-mentioned criteria. It is freeware and runs on a standard x86 personal computer with a Microsoft Windows operating system. In this work, the authors conducted simulations using the ENVImet model (rel. 3.5) in order to quantify the effects of selected mitigation actions in one of the most characteristic areas of Padua, Prato della Valle.

ENVImet is a three-dimensional microclimate model designed to simulate the surface-plant-air interactions in the urban environment with a typical resolution of 0.5 to $10 \mathrm{~m}$ in space and $10 \mathrm{~s}$ in time. The model area is described in Figure 1. The main area is a $111 \times 88 \times 35$ grid (in a $x, y, z$ tridimensional reference system), with a $5 \times 5 \times 3 \mathrm{~m}$ grid dimension. An appropriate number of nesting grids (five) was set in order to minimize boundary effects. Seven specific points of interest were identified in the zone to characterize the dry-bulb air temperature (AT), the mean radiant temperature (MRT) and the predicted mean vote (PMV) at $1.80 \mathrm{~m}$ above ground during 24 hours, from $6 \mathrm{am}$ to $6 \mathrm{pm}$ (Table 1). Because the simulations were very time-consuming, they lasted 72 hours; only the last 24 hours were considered for the results because they were the least influenced by the initial and boundary conditions. The daily mean air temperature of the day before the start simulation was used as the initial air temperature at $6 \mathrm{am}$ of the first day. Simulations used the default values of ENVImet except for the ones reported in Table 2. 


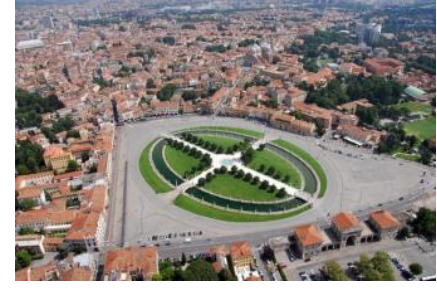

a)

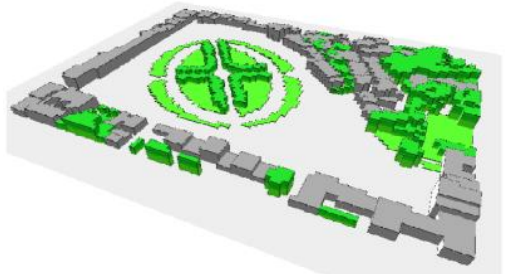

b)

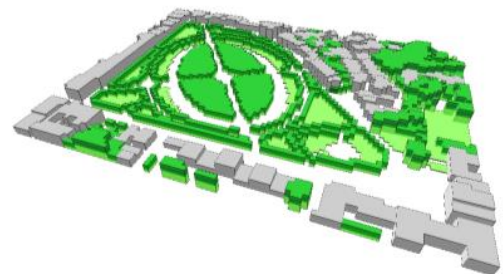

c)

Figure 1 - The area (a) and the model area in ENVImet used for the simulations of the "AsIs" scenario (b) and the "Green ground" scenario (c)

Table 1 - Description of the seven characteristic points in the two simulated scenarios

\begin{tabular}{|c|c|c|c|}
\hline & $\begin{array}{l}\text { Posi- } \\
\text { tion }\end{array}$ & $\begin{array}{l}\text { Scenario } \\
\text { "AsIs" }\end{array}$ & $\begin{array}{l}\text { Scenario } \\
\text { "Green } \\
\text { ground" }\end{array}$ \\
\hline 4 & 1 & $\begin{array}{l}\text { Asphalt - } \\
\text { far from } \\
\text { buildings }\end{array}$ & $\begin{array}{l}\text { Green - } \\
\text { far from } \\
\text { water }\end{array}$ \\
\hline & 2 & $\begin{array}{l}\text { Asphalt - } \\
\text { near to } \\
\text { buildings }\end{array}$ & $\begin{array}{l}\text { Asphalt - } \\
\text { near to } \\
\text { buildings }\end{array}$ \\
\hline & 3 & $\begin{array}{l}\text { Gravel - } \\
\text { near to } \\
\text { water }\end{array}$ & $\begin{array}{l}\text { Gravel - } \\
\text { near to } \\
\text { water }\end{array}$ \\
\hline & 4 & $\begin{array}{l}\text { Gravel - } \\
\text { far from } \\
\text { water }\end{array}$ & $\begin{array}{l}\text { Gravel - } \\
\text { far from } \\
\text { water }\end{array}$ \\
\hline & 5 & $\begin{array}{l}\text { Green - } \\
\text { far from } \\
\text { water }\end{array}$ & $\begin{array}{l}\text { Green - } \\
\text { Trees }\end{array}$ \\
\hline Fim & 6 & $\begin{array}{l}\text { Green - } \\
\text { near to } \\
\text { water }\end{array}$ & $\begin{array}{l}\text { Green - } \\
\text { Trees }\end{array}$ \\
\hline & 7 & $\begin{array}{l}\text { Green - } \\
\text { Trees }\end{array}$ & $\begin{array}{l}\text { Green - } \\
\text { Trees }\end{array}$ \\
\hline
\end{tabular}

It is worth stressing that while other indexes (like PET and $\mathrm{SET}^{*}$ ) were specifically defined to assess outdoor thermal comfort (Matzarakis et al., 2007) (Matzarakis et al., 2010) (Mayer, 1993) (Gagge et al., 1986) (Höppe, 1999) (Mayer and Höppe, 1987), the use of PMV is not universally recognized. In addition, the ISO 7730 standard focused on the use of PMV only as the indoor thermal comfort index. Nevertheless, some authors applied the use of PMV to outdoor environments (Matzarakis et al., 2007) (Matzarakis et al., 2010), (Berkovic et al., 2012) (Honjo, 2009) (Jendritzky and Nubler, 1981) (Jendritzky, 1993) (Thorsson et al., 2004). ENVImet uses the Klima-Micheal-Model (KMM) that adds complex energy balance equations referred to outdoor to the classic Fanger's model (Jendritzky
Table 2 - Configuration values in ENVImet

\begin{tabular}{|c|c|}
\hline Simulation tool: ENVI-met 3.5 & \\
\hline Start Simulation at Day & \\
\hline (DD.MM.YYYY): & Building properties \\
\hline 27.07.2012 (Summer) & Inside Temperature \\
\hline Start Simulation at Time & {$[K]=298$} \\
\hline (HH:MM:SS) = 06:00:00 & Heat Transmission \\
\hline Total Simulation Time in & Walls $\left[\mathrm{W} \mathrm{m} \mathrm{m}^{-2} \mathrm{~K}^{-1}\right]=1$ \\
\hline Hours $=72.00$ & Heat Transmission \\
\hline Save Model State each $? \min =$ & Roofs $\left[\mathrm{W} \mathrm{m} \mathrm{m}^{-2} \mathrm{~K}^{-1}\right]=2$ \\
\hline 60 & Albedo Walls = 0.2 \\
\hline Wind Speed at $10 \mathrm{~m}$ ab. & Albedo Roofs $=0.3$ \\
\hline ground $\left[\mathrm{m} \mathrm{s}^{-1}\right]=2$ & Emissivity of all the \\
\hline Wind Direction (0:N.. 90:E.. & surfaces $=0.9$ \\
\hline 180:S.. 270:W..) = 45 & \\
\hline Roughness Length z0 at & People velocity [ $\left.\mathrm{m} \mathrm{s}^{-1}\right]$ \\
\hline Reference Point $=0.2$ & $=0.3$ \\
\hline Initial Temperature & Metabolic rate $\left[\mathrm{W} \mathrm{m}^{-2}\right]$ \\
\hline Atmosphere $[\mathrm{K}]=299.1 \mathrm{~K}$ & $=116$ \\
\hline Specific Humidity at $2500 \mathrm{~m}$ & Clothing insulation \\
\hline$\left[g_{\text {water }} / \mathrm{kg}_{\text {air }}\right]=7$ & {$[\mathrm{clo}]=0.5$} \\
\hline $\begin{array}{l}\text { Relative Humidity at } 2 \mathrm{~m}[\%]= \\
76\end{array}$ & \\
\hline
\end{tabular}

and Nübler, 1981) (Honjo, 2009).

To measure the UHII, a set of simulations were performed in the rural zone just outside Padua (Via Roma in Legnaro) as well, in order to calculate a temperature profile for the reference zone. Two scenarios were supposed besides the actual one ("AsIs" scenario):

a) "Green ground": increasing the pervious surfaces of the area from $23 \%$ to $43 \%$ by planting trees, $10 \mathrm{~m}$ height, within and around the ellipse, and converting a large part of the impervious zone - e.g. asphalt car park surface - to a pervious zone by planting grass. The circle street was left in order not to modify the traffic (Figure 1). The main effects were: Sky View Factor (SVF) decreased for the presence 
of trees along the streets; impervious surface fraction decreased (and pervious surface fraction increased) because the green area increased; the albedo slightly increased; other thermo-physical properties of the surfaces/materials remained more or less the same. The impact on UHII reduction was the air cooling mainly due to the evapotranspiration effect of the green surfaces.

b) "Cool pavements": substituting all the traditional asphalt (albedo 0.2) and concrete (albedo 0.4) of roads and pavements with "cool materials", that is materials with higher albedo (0.5) and also high emissivity in the infrared radiation. The main effect was a significant increase in the albedo while other properties remained the same. The impact on UHII reduction was mainly due to the minor air heating caused by the lower urban surfaces' temperature; the limitation in the solar radiation absorption and the high emissivity of this kind of surfaces were the main causes.

It is worth highlighting that in case b) ENVImet has some limitations; in fact it is not possible to simulate:

- pervious asphalts or green/asphalt mixed surfaces (the only pervious surface that can be modelled is the soil beneath the green and pavements);

- surfaces with phase change materials, able to limit the temperature thanks to the melting process of the micro-incapsulated nanomaterials inside;

- $\quad$ asphalts/concretes with light pigments, able to reflect most part of the visible radiation;

- different emissivity values for different range of wavelenght (that is ENVImet considers all the surfaces as greys).

For all these reasons the "Cool pavements" scenario was simulated only by the increased albedo of asphalt and concrete surfaces.

\subsection{Results and Discussion}

Results, in terms of AT, UHII with respect to Via Roma (rural zone), MRT and PMV (at $1.80 \mathrm{~m}$ above ground), are summarized in Table 3 and Table 4 for the seven points (the most significant of Table 1 as representative of the area) respectively for a typical daytime and night time hour. Summarizing, the main results are:

- In terms of AT, differences between the different points on the square are never greater than $1.5^{\circ} \mathrm{C}$. This is in line with other studies (Iziomon Moses et al., 1999) (Bruse et al., 2009). Experimental studies show that the green surfaces absorb almost a quarter of the solar radiation allowing a lower outside adduction heat exchange with respect to traditional impervious surfaces (even lower with wet green); the evapotranspiration effect allows a further heat exchange (higher with wet green) so that green surfaces' temperature is normally lower than impervious ones, even lower the wetter the green is (Lazzarin et al., 2005). ENVImet does not allow us to force the ground humidity, i.e. simulating watering of green surfaces; considering that, as previously stated, simulations lasted 72 hours but only the last 24 hours were considered for the results, the green surfaces were substantially dry, thus limiting their performances.

- UHI intensity assumes high values in the AsIs scenario: the highest temperatures $\left(8-9^{\circ} \mathrm{C}\right)$ was noticed after the sunset $(8 \mathrm{pm})$ and till the first sunrise (4am).

- a quite similar value $\left(7.7^{\circ} \mathrm{C}\right)$ for the UHII during the day was noticed only for point 2, which is a point on the asphalt near the buildings (characterized by low SVF and impervious surface); for the other points the maximum daytime UHI intensity was always lower or equal to $7^{\circ} \mathrm{C}$.

- $\quad$ AT in Pos. 3 (gravel near to water) is probably overestimated, as ENVImet is not able to simulate moving water systems like rivers and fountains (Bruse and Fleer, 1998) so there is no evaporative cooling effect. This affects both AT and PMV (Bisson, 2010).

- $\quad$ MRT in the AsIs scenario is almost the same in the different points at $3 \mathrm{pm}$, except for the ones shadowed by trees (Pos. 2 and 7); such very large differences in MRT are consistent with other studies (Iziomon Moses et al., 1999) (Mayer, 1993) (Bruse et al., 2008). A main 
consequence is the very great values of PMV (greater than 6 in the most exposed positions) indicating a sensation of great heat and so of great discomfort. However, as reported in literature (Bruse and Fleer, 1998) (Bruse, 2005) (Candidi et al., 2006) (Honjo, 2009) (Thorsson et al., 2004) (Baker et al., 2001) values of PMV over the scale $-4 /+4$ are not significant, indicating a great discomfort sensation.

- The "Green ground" UHI mitigation strategy allowed around a $1^{\circ} \mathrm{C}$ decrease in UHI maximum night time intensity (but till $2{ }^{\circ} \mathrm{C}$ decrease in day time intensity). The greatest advantage from the mitigation action was recorded on the asphalt (points 1 and 2, but greater on point 2 with lower SVF). Note that, while Pos. 1 passes from asphalt to green surface, Pos. 2 remains the same: increasing the green has an effect on reducing AT both directly (Pos. 1, reduction of 0.8 and $1.5{ }^{\circ} \mathrm{C}$ respectively at $3 \mathrm{am}$ and $3 \mathrm{pm}$ ) and indirectly (Pos. 2, reduction respectively of 1 and $2.3^{\circ} \mathrm{C}$ ). This affects the PMV reducing its values, also considering the decrease in MRT in positions where trees were planted (Pos. 1 and 5). It could be concluded that even small but near green areas have a positive effect on reducing AT and so UHII, as proved also by (Candidi et al., 2006) (Jauregui, 1990) (Abu et al., 1998) (Gaj et al., 1998) (Cubasch et al., 2012).

Table 3 - Data obtained by ENVImet simulations for the three scenarios on July, $29^{\text {th }}$, $3 \mathrm{pm}$

\begin{tabular}{|c|c|c|c|c|c|c|c|c|}
\hline & & Pos.1 & Pos.2 & Pos.3 & Pos.4 & Pos.5 & Pos.6 & Pos.7 \\
\hline \multirow{4}{*}{ AsIs } & $\operatorname{AT}\left({ }^{\circ} \mathrm{C}\right)$ & 36.1 & 36.9 & 35.8 & 36.0 & 36.2 & 35.7 & 35.4 \\
\hline & UHII $\left({ }^{\circ} \mathrm{C}\right)$ & 6.9 & 7.7 & 6.6 & 6.9 & 7.0 & 6.5 & 6.2 \\
\hline & $\operatorname{MRT}\left({ }^{\circ} \mathrm{C}\right)$ & 80.2 & 40.9 & 70.9 & 70.9 & 81.3 & 65.0 & 36.8 \\
\hline & PMV & 6.7 & 3.6 & 5.9 & 6.1 & 6.8 & 5.3 & 3.1 \\
\hline \multirow{4}{*}{$\begin{array}{l}\text { Green } \\
\text { ground }\end{array}$} & $\operatorname{AT}\left({ }^{\circ} \mathrm{C}\right)$ & 34.6 & 34.6 & 34.4 & 34.6 & 34.1 & 34.1 & 34.2 \\
\hline & UHII $\left({ }^{\circ} \mathrm{C}\right)$ & 5.4 & 5.5 & 5.3 & 5.5 & 5.0 & 5.0 & 5.0 \\
\hline & $\operatorname{MRT}\left({ }^{\circ} \mathrm{C}\right)$ & 70.2 & 39.7 & 70.5 & 70.9 & 35.3 & 65.4 & 35.5 \\
\hline & PMV & 5.7 & 3.2 & 5.7 & 5.8 & 2.8 & 5.2 & 2.8 \\
\hline \multirow{4}{*}{$\begin{array}{l}\text { Cool } \\
\text { Pavements }\end{array}$} & $\operatorname{AT}\left({ }^{\circ} \mathrm{C}\right)$ & 32.3 & 33.0 & 32.2 & 32.6 & 32.5 & 32.2 & 31.9 \\
\hline & UHII $\left({ }^{\circ} \mathrm{C}\right)$ & 3.1 & 3.8 & 3.1 & 3.4 & 3.4 & 3.0 & 2.7 \\
\hline & $\operatorname{MRT}\left({ }^{\circ} \mathrm{C}\right)$ & 85.3 & 35.6 & 68.1 & 68.2 & 77.7 & 62.2 & 32.4 \\
\hline & PMV & 6.0 & 2.6 & 5.0 & 5.0 & 5.6 & 4.5 & 2.2 \\
\hline
\end{tabular}

Table 4 - Data obtained by ENVImet simulations for the three scenarios on July, 30th, 3am

\begin{tabular}{|c|c|c|c|c|c|c|c|c|}
\hline & & Pos.1 & Pos. 2 & Pos.3 & Pos.4 & Pos. 5 & Pos. 6 & Pos.7 \\
\hline \multirow{4}{*}{ AsIs } & $\mathrm{AT}\left({ }^{\circ} \mathrm{C}\right)$ & 29.1 & 29.3 & 28.8 & 29.0 & 28.8 & 28.7 & 28.6 \\
\hline & UHII $\left({ }^{\circ} \mathrm{C}\right)$ & 8.4 & 8.6 & 8.1 & 8.4 & 8.1 & 8.1 & 8.1 \\
\hline & $\operatorname{MRT}\left({ }^{\circ} \mathrm{C}\right)$ & 23.0 & 22.5 & 18.5 & 18.4 & 19.6 & 17.5 & 18.8 \\
\hline & PMV & 1.1 & 1.1 & 0.8 & 0.8 & 0.8 & 0.7 & 0.8 \\
\hline \multirow{4}{*}{$\begin{array}{l}\text { Green } \\
\text { ground }\end{array}$} & $\mathrm{AT}\left({ }^{\circ} \mathrm{C}\right)$ & 28.3 & 28.3 & 28.2 & 28.2 & 27.8 & 27.9 & 28.1 \\
\hline & UHII $\left({ }^{\circ} \mathrm{C}\right)$ & 7.6 & 7.6 & 7.5 & 7.6 & 7.1 & 7.3 & 7.4 \\
\hline & $\operatorname{MRT}\left({ }^{\circ} \mathrm{C}\right)$ & 18.3 & 21.9 & 12.7 & 19.3 & 18.0 & 18.3 & 18.1 \\
\hline & PMV & 0.7 & 0.9 & 0.7 & 0.7 & 0.6 & 0.6 & 0.6 \\
\hline \multirow{4}{*}{$\begin{array}{l}\text { Cool } \\
\text { Pavements }\end{array}$} & $\mathrm{AT}\left({ }^{\circ} \mathrm{C}\right)$ & 27.4 & 27.6 & 27.2 & 27.4 & 27.2 & 27.2 & 27.1 \\
\hline & UHII $\left({ }^{\circ} \mathrm{C}\right)$ & 6.7 & 6.9 & 6.5 & 6.7 & 6.5 & 6.5 & 6.4 \\
\hline & $\operatorname{MRT}\left({ }^{\circ} \mathrm{C}\right)$ & 20.7 & 20.2 & 16.8 & 16.9 & 17.5 & 15.9 & 16.8 \\
\hline & PMV & 0.6 & 0.7 & 0.4 & 0.4 & 0.4 & 0.3 & 0.4 \\
\hline
\end{tabular}




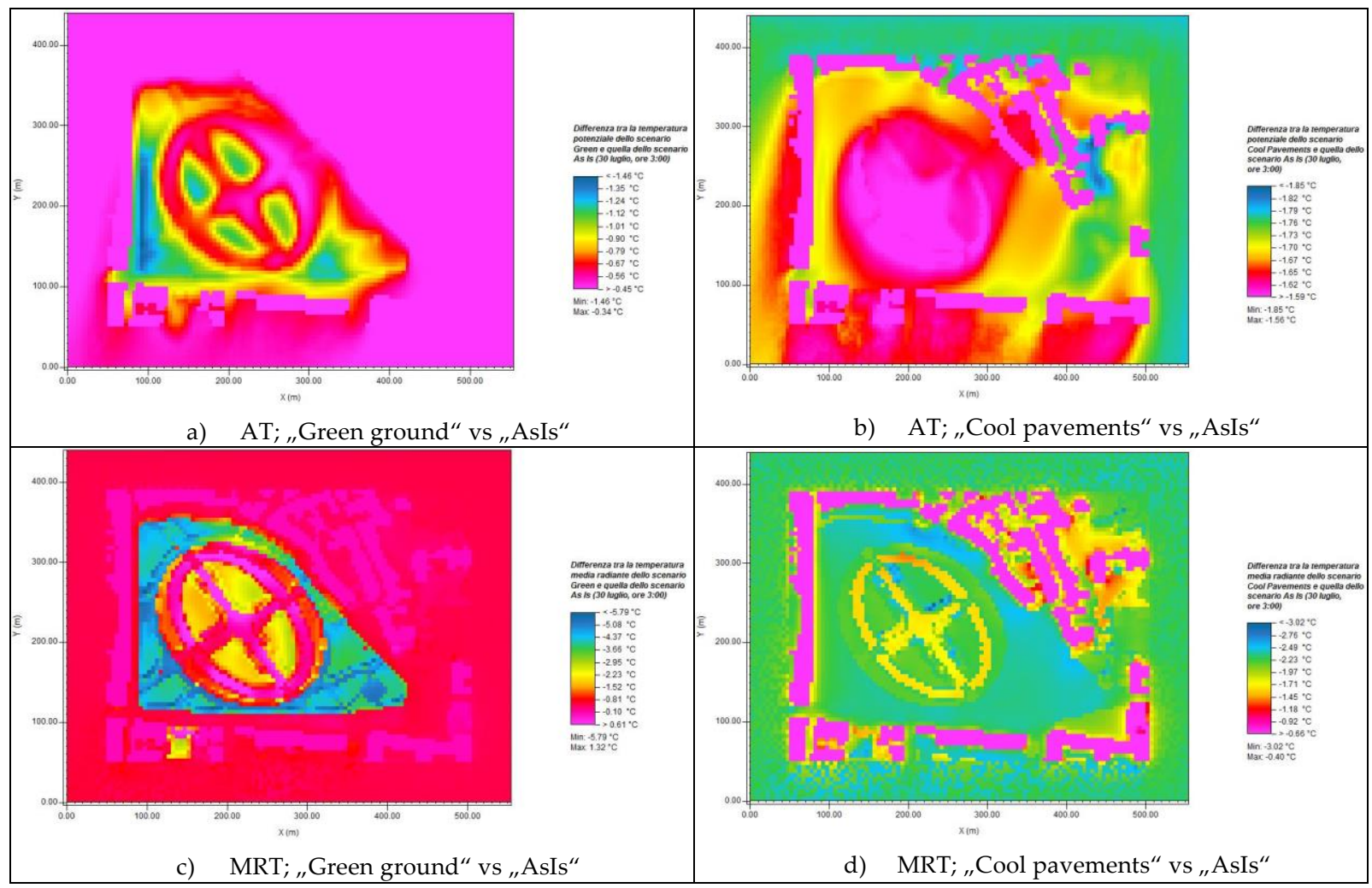

Fig. 2 - Air temperature (a) - b) ) and mean radiant temperature (c) - d) ) at $1.80 \mathrm{~m}$ above the ground at 3am on 30th July: comparison between "Green ground" and „Asls" scenarios ( a) - c) ) and between "Cool pavements" and "Asls" scenarios (b) - d) )

- It is important to note that the positive effect of the "Green ground" mitigation action is mainly due to the shadowing effect of trees (during daytime); this could be detrimental during night time if the foliage were too dense because of the reduced SVF, also considering the already cited limit of the model to simulate green watering.

- The "Cool pavements" UHI mitigation strategy allowed around a $1.5-2{ }^{\circ} \mathrm{C}$ decrease in UHII at 3 am and till $3-4{ }^{\circ} \mathrm{C}$ at $3 \mathrm{pm}$. This positive effect is mainly due to the increased albedo of asphalt and the connected reduced surface temperature (for example in Pos. 1 at $3 \mathrm{pm}$ the asphalt temperature decreases from $51.9^{\circ} \mathrm{C}$ to $42.6^{\circ} \mathrm{C}$ ). Such results are in line with other studies: (Akbari et al. 2001) found that increasing albedo by 0.25 allows a surface temperature decrease of $10{ }^{\circ} \mathrm{C}$; in other cases, introducing cool materials with albedo between 0.4 and 0.85 brings the surface temperature to decrease by $7.5-15{ }^{\circ} \mathrm{C}$ and AT to decrease by $4{ }^{\circ} \mathrm{C}$ (daytime) and $2{ }^{\circ} \mathrm{C}$ (night time) (Berdahl and Bretz, 1997) (Livada et al., 2006). Also considering the MRT, the "Cool pavements" mitigation action is positive, allowing a greater decrease with respect to the "AsIs" and "Green ground" scenarios. Only in Pos. 1, which is in the asphalt far from buildings, does MRT increase with cool materials, due to the greater reflected radiation during the day. This mitigation action allows to decrease the PMV inside the comfort range $(-0.5 /+0.5)$ during the night for most positions.

- Comparing the distribution of the differences between the two mitigation actions and the "AsIs" scenario for both AT and MRT at 3am (Fig. 2): the "Cool pavements" scenario allows a slightly greater and more uniform reduction on AT with respect to the "Green ground", while referring to MRT the latter seems to perform better than the former. 


\section{Conclusions}

The experimental analyses highlighted the presence of a not negligible UHI effect also in medium-size cities like Padua of up to $6-7^{\circ} \mathrm{C}$, resulting in a thermal stress for people living in urban environments. The UHI phenomenon was very intense in the old town, where streets are characterized by highH/W ratio, small SVF and no presence of pervious surfaces. However, in residential areas, the UHI intensity was lower on average with a decreasing trend going from more densely populated streets to less densely populated ones.

In order to test different possible mitigation actions, the particular case of Prato della Valle was studied by the ENVImet model. Introducing new green areas instead of impervious ones allows a decrease in AT till $2{ }^{\circ} \mathrm{C}$ and in MRT until some ten degrees. Even more interesting results can be reached using cool materials, even if the model presents some limits in modelling these kind of surfaces. The study highlights that possible advantages in mitigating UHI effect are possible installing small green areas and introducing new materials when maintenance operations of the pavements are foreseen.

\section{Nomenclature}

\section{Symbols}

$\begin{array}{lll}\text { AT } & \text { air temperature } & { }^{\circ} \mathrm{C} \\ \text { MRT } & \text { mean radiant temperature } & { }^{\circ} \mathrm{C} \\ \text { PET } & \begin{array}{l}\text { physiological equivalent } \\ \text { temperature }\end{array} & { }^{\circ} \mathrm{C} \\ & \text { predicted mean vote } & \\ \text { PMV } & \text { new standard effective } & { }^{\circ} \mathrm{C} \\ \text { SET* } & \text { temperature } & \\ & \text { sky view factor } & \\ \text { UHI } & \text { urban heat island } \\ \text { UHII } & \text { urban heat island intensity } & { }^{\circ} \mathrm{C}\end{array}$

\section{References}

Abu, E.M., T. Asaeda, V.T. Ca. 1998. “Reduction in air conditioning energy caused by a nearby park". Journal of Energy and Buildings 29: 8392.
Akbari, H., M. Pomerantz, H. Taha. 2001. “Cool surfaces and shade trees to reduce energy use and improve air quality in urban areas". Solar Energy 70 (3): 295-310.

Bacci, P., M. Maugeri. 1992. "The urban heat island of Milan". Il Nuovo Cimento C 15(4): 417-424. doi:10.1007/BF02511742.

Baker, N., M. Nikolopoulou, K. Steemers. 2001. "Thermal comfort in outdoor urban spaces: understanding the human parameter". Solar Energy 70(3): 227-235.

Berdahl, P., S. E. Bretz. 1997. “Preliminary survey of the solar reflectance of cool roofing materials". Energy and Buildings 25: 149- 158.

Berkovic, S., A. Yezioro, A. Bitan. 2012. "Study of thermal comfort in courtyards in a hot arid climate". Solar Energy 86: 1173-1186.

Bisson, M. A.Y. 2009/2010. “Simulazione del microclima urbano di Milano mediante il software ENVI-met: studio degli effetti dell'inserimento di aree verdi sulla sollecitazione termica degli edifici" ("Simulation of the urban microclimate of Milan by ENVI-met model: study of green areas in buildings performance", in Italian). Master's Degree Thesis. Supervisor Prof. Luca Pietro Gattoni. Politecnico di Milano.

Blazejczyk, K., Y. Epstein., G. Jendritzky, H. Staiger, B. Tinz. 2012. "Comparison of UTCI to selected thermal indices". International Journal of Biometeorology 56: 515-535. doi:10.1007/s00484-011-0453-2.

Bonafè, G. (edited by) (ARPA Emilia-Romagna). 2006. "Microclima urbano: impatto dell'urbanizzazione sulle condizioni climatiche locali e fattori di mitigazione" ("Urban microclimate: urbanization impact on the local climatic conditions and mitigation factors", in Italian).

Bruse, M., H. Fleer. 1998. “Simulating surface-plant air interactions inside urban environments with a three dimensional numerical model". Environtal Modelling and Software 13: 373-384.

Bruse, M. 2005. “Assessing urban microclimate from the user's perspective - Multi-Agent systems as a new tool in urban biometeorology". Annalen der Meteorologie 41: 137-140. 
Bruse, M., P. Dostal, S. Huttner. 2008. “Using ENVI-met to simulate the impact of global warming on the microclimate in central European cities". Berichte des Meteorologischen Instituts der Albert-LudwigsUniversität Freiburg Nr. 18. Helmut Mayer e Andreas Matzarakis (eds.). 5th JapaneseGerman Meeting on Urban Climatology. 307312.

Bruse, M., P. Dostal, S. Huttner, A. Katzschner. 2009. "Strategies For Mitigating Thermal Heat Stress In Central European Cities: The Project Klimes", The seventh International Conference on Urban Climate. 29 June - 3 July 2009. Yokohama. Japan.

Busato, F., R. Lazzarin, M. Noro. 2014. “Three years of study of the Urban Heat Island in Padua: Experimental results". Sustainable Cities and Society 10: 251-258. doi:10.1016/j.scs.2013.05.001.

Candidi, P., G. Galli, A. Vallati. 2006. "Studio dell'influenza di diversi materiali di rivestimento sul microclima di aeree urbane in piccola scala" ("Study of the influence of different covering materials on microclimate of urban areas", in Italian). $61^{\circ}$ National Congress ATI - Perugia.

Cubasch, U., I. Langer, S. Sodoudi. 2012. “Using the ENVI-MET program to simulate the micro climate in new Town HASHTGERD". The International Conference on Computing, Networking and Digital Technologies (ICCNDT2012) - Bahrain, 61-64.

Fabrizi, R., S. Bonafoni, R. Biondi. 2010. “Satellite and Ground-Based Sensors for the Urban Heat Island. Analysis in the City of Rome". Remote Sens 2: 1400-1415. doi:10.3390/rs2051400.

Gagge, A. P., A. P. Fobelets, L. G. Berglund. 1986. "A standard predictive index of human response to the thermal environment". ASHRAE Trans 92: 709-731.

Gaj, E., F. Gomez, A. Reing. 1998. “Vegetation and climatic changes in a city". Ecological Engeneering 10: 355-360.

Giovannini, L., D. Zardi, M. De Franceschi. 2011. "Analysis of the Urban Thermal Fingerprint of the City of Trento in the Alps". Journal of
Applied Meteorology and Climatology 50: 1145-1162.

Honjo, T. 2009. "Thermal comfort in outdoor environment". Global Environmental Research 13: 43-47.

Höppe, P. 1999. "The physiological equivalent temperature-a universal index for the biometeorological assessment of the thermal environment". International Journal of Biometeorology 43: 71-75.

Huttner, S. 2012. "Further development and application of the 3D microclimate simulation ENVI-met". Ph.D. Thesis, Johannes GutenbergUniversität Mainz, Germany.

Iziomon Moses, G., A. Matzarakis, H. Mayer. 1999. "Applications of a universal thermal index: physiological equivalent temperature". International Journal of Climatology 43: 76-84.

Jauregui, E. 1990. “Influence of a large urban park on temperature and convective precipitation in a tropical city". Journal of Energy and Buildings 15-16: 457-463.

Jendritzky, G., W. Nubler. 1981. “A model analysing the urban thermal environment in physiologically significant terms". Meteorology and Atmospheric Physics 29: 313-326.

Jendritzky, G. 1993. "The atmospheric environment-an introduction". Experientia 49(9): 733-740. doi:10.1007/BF01923541.

Lazzarin, R., F. Castellotti, F. Busato. 2005. "Experimental measurements and numerical modelling of a green roof". Energy and Buildings 37:1260-1267. doi:10.1016/j.enbuild.2005.02.001.

Lazzarin, R. 2011. "Le isole di calore nelle aree urbane" ("Urban heat islands", in Italian). Casa\&Clima 34: 34-40.

Livada, I., M. Santamouris, A. Synnefa. 2006. “A study of the thermal performance of reflective coatings for the urban environment". Solar Energy 80: 968-981.

Lora, C., M. De Franceschi, M. Sitta, D. Zardi. 2006. "Determinazione dell'effetto "isola di calore urbana" in una città alpina mediante l'utilizzo di reti di sensori a basso costo" ("Determination of the "urban heat Island" effect in an Alpine city by using low cost sensors", in Italian). 
Proceedings of XXXth Conference on hydraulic and hydraulic constructions-IDRARome. Italy.

Matzarakis, A., F. Rutz, H. Mayer. 2007. "Modelling radiation fluxes in simple and complex environments - application of the RayMan model". International Journal of Biometeorology 51: 323-334.

Matzarakis, A., F. Rutz, H. Mayer. 2010. "Modelling Radiation fluxes in simple and complex environments - Basics of the RayMan model". International Journal of Biometeorology 54: 131-139.

Mayer, H., P. Höppe. 1987. “Thermal comfort of man in different urban environments". Theor Appl Climatol 38: 43-49.

Mayer, H. 1993. "Urban bioclimatology". Experientia 49: 957-963.

Noro, M., R. Lazzarin, F. Busato. Pre-published online January, 13, 2014a. “Urban heat island in Padua, Italy: experimental and theoretical analysis". Indoor and Built Environment doi: 10.1177/1420326X13517404.

Noro, M., F. Busato, R. Lazzarin. 2014b. “UHI effect in the city of Padua: simulations and mitigation strategies using the RayMan and ENVImet model". Geographia Polonica 87(4): 517-530. doi: 10.7163/GPol.2014.35.

Noro, M., R. Lazzarin. 2014. “Theoretical and experimental analysis of the UHI effect in a medium size city of Italy". Proceedings "3th International Conference on Countermeasures to Urban Heat Island". Venice, paper ref. 143, 1012-1023, ISBN 978-88-906958-2-7.
Petralli, M., L. Massetti, S. Orlandini. 2009. “Air temperature distribution in an urban park: differences between open-field and below a canopy". The seventh International Conference on Urban Climate, Yokohama, Japan.

Petralli, M., L. Massetti, S. Orlandini. 2011. “Five years of thermal intra-urban monitoring in Florence (Italy) and application of climatological indices". Theor Appl Climatol 104: 349-356. doi:10.1007/s00704-010-0349-9.

Petralli, M., A. Prokopp, M. Morabito, G. Bartolini, T. Torrigiani, S. Orlandini. 2006. "Ruolo delle aree verdi nella mitigazione dell'isola di calore urbana: uno studio nella città di Firenze" ("The role of green areas in UHI mitigation: a study in the city of Florence", in Italian). Rivista Italiana di Agrometeorologia 1: 51-58.

Santamouris, M. 2007. Advances in Building Energy Research: v1. Earthscan Ltd. ISBN-13: 978-1844073894.

Thorsson, S., M. Lindqvist, S. Lindqvist. 2004. "Thermal bioclimatic conditions and patterns of behaviour in an urban park in Göteborg, Sweden". International Journal of Biometeorology 48: 149-156.

Xiaoshan, Y., L. Zhao, M. Bruse, Q. Meng. 2012. "An integrated simulation method for building energy performance assessment in urban environments". Energy and Buildings 54: 243251.

Zauli Sajani, S., S. Tibaldi, F. Scotto, P. Lauriola. 2008. "Bioclimatic characterisation of an urban area: a case study in Bologna (Italy)". International Journal of Biometeorology 52: 779-785. doi:10.1007/s00484-008-0171-6. 